\title{
Narrativa do terror e do sofrimento: relato materno sobre o desaparecimento forçado do filho
}

\author{
Fábio Araujo \\ Doutorando em Sociologia (Universidade Federal do Rio de Janeiro) \\ Professor do Instituto Federal de Educação, Ciência e Tecnologia do Rio de Janeiro \\ fabioaaraujoster@gmail.com
}

\begin{abstract}
Resumo O desaparecimento forçado de pessoas foi usado como método de repressão durante os regimes militares latino-americanos; atualmente, corresponde a uma prática do repertório da linguagem da violência urbana. Neste artigo apresento e analiso os relatos de uma mãe acerca do desaparecimento do filho, protagonizado por "traficantes de drogas" em parceria com policiais. O relato dessa mãe é emblemático, constituindose numa verdadeira narrativa do terror e do sofrimento, e meu interesse principal é retraçar essa história de dor, explorando a contundência do relato coletado.
\end{abstract}

Palavras-chave: Desaparecimento forçado, luto, familiar de vítima, favela, maternidade.

\section{Introdução}

U MA DAS IMAGENS MAIS MARCANTES que ficaram das ditaduras latinoamericanas foi a figura do desaparecido. ${ }^{1} \mathrm{O}$ desaparecimento forçado era utilizado como método de repressão pelos militares que acreditavam ter descoberto uma espécie de crime perfeito. Entretanto, o desaparecimento forçado de pessoas não foi exclusividade dos regimes ditatoriais, o período democrático também tem produzido seus desaparecidos. Meu argumento é o de que o desaparecimento forçado de pessoas tornou-se uma prática que compõe o repertório da linguagem da violência urbana na cidade do Rio de Janeiro e região metropolitana.

O desaparecimento forçado se inicia com a captura violenta e arbitrária da pessoa, que em seguida é levada para lugares desconhecidos onde, na maioria dos casos, é torturada e assassinada sem que se deixem indícios ou rastros do corpo, dos lugares por onde esteve detida, nem de quem perpetrou o crime. Em muitos casos, os corpos são mutilados para dificultar sua identificação ou características da morte, e as pessoas podem ser levadas a prisões clandestinas onde podem ser objeto de agressões físicas. Com o objetivo de se desfazerem do cadáver, os responsáveis ainda chegam a enterrar os corpos em cemitérios clandestinos, jogá-los em rios, esquartejar os corpos e espalhar os pedaços em diferentes lugares, ou mesmo oferecer os corpos a animais para que sejam comidos e não se deixe qualquer vestígio da vítima. $\mathrm{O}$ desapa-

1. Desaparecido: termo usado para se referir às pessoas que sumiram, sem deixar informações, e sem que ninguém saiba do seu paradeiro. O desaparecimento pode ser voluntário ou involuntário. 
recimento pode ser pensado como um "evento crítico" (Das, 1995) por provocar rupturas no cotidiano e processos de subjetivação pela via da violência e do sofrimento naqueles que são atingidos direta e indiretamente pelo acontecimento.

Neste artigo apresento e analiso os relatos de uma mãe acerca do desaparecimento do filho, protagonizado por "traficantes de drogas" em parceria de policiais. Como o relato dessa mãe é emblemático, constituindo uma verdadeira narrativa do terror e do sofrimento, meu interesse principal é retraçar essa história de dor, aproveitando a contundência do relato coletado. Esta entrevista, em particular, apresenta certo contraste em relação às demais realizadas pelo fato de ser extremamente rica em termos de densidade e qualidade do relato.

O material empírico que fundamenta este trabalho - uma entrevista específica - é parte de um conjunto maior de entrevistas realizadas com familiares de pessoas desaparecidas para minha tese de doutorado que tem como tema o desaparecimento forçado de pessoas. Foram realizadas 25 entrevistas cujo aspecto marcante é a ausência de informações sobre as circunstâncias do acontecimento. Porém, no caso particular a ser apresentado ocorre o oposto: muitas informações e pistas aparecem para situar esse desaparecimento no quadro da violência urbana e da insegurança pública. Nesse sentido, priorizei nessa oportunidade menos uma reflexão teórica e mais uma "descrição densa" do caso, valendo-me do relato traumático. ${ }^{2}$

O quadro cognitivo que conforma o regime de ação dessa mãe tem como núcleo central a situação dolorosa do desaparecimento do filho e a possibilidade de que ele esteja morto. A compreensão da morte do filho não como uma fatalidade, como é geralmente argumentado por policiais, mas sim como fruto de uma injustiça, impulsiona e alimenta uma vontade, praticamente uma missão de fazer justiça por parte da mãe. E nesse processo de lutar por justiça, nos embates travados, a polícia e os traficantes são os alvos centrais das críticas. Nas críticas feitas à polícia, a forma é marcada pela linguagem das emoções (a dor, a indignação, a raiva, o sofrimento, o luto, a humilhação, as ofensas morais, o amor aos filhos), e o conteúdo pelo questionamento de uma "humanidade comum" (Boltanski, 2000).

Agir diante de um regime de humanização/desumanização implica situar-se em um jogo de disputas, denúncias, críticas e acusações em que as posições e os lugares de cada um, em que pesem as hierarquias so- ciais, são intercambiáveis e podem mudar conforme o desenrolar das situações de denúncia. O regime de humanização/desumanização, em um de seus aspectos, pode ser entendido como um continuum de posições intercambiáveis dentro de um sistema actancial em que os actantes ora podem acionar recursos e dispositivos de humanização, ora de desumanização, ora são vítimas da desumanização, ora algozes da desumanização.

É nesse contexto do "agir competente", por parte dos atores envolvidos numa situação, que vão se "fabricando", "inventando", "conformando" os princípios e as gramáticas morais e políticas que coordenam as ações de cada um. É nessa trama que se situa o agir e a produção de sentido dessa mãe que luta por esclarecer o desaparecimento do filho.

\section{Sobre a situação de entrevista e o trabalho de campo}

No final do ano de 2005, mais um evento traumático chocou a cidade do Rio de Janeiro: o desaparecimento de treze jovens da Favela Samambaia. O primeiro registro que fiz desse caso foi através do material jornalístico que circulou. No dia 23 de setembro de 2006, durante um evento na sede da Associação Brasileira de Imprensa (ABI), organizado pelo Fórum de Reparação do Estado do Rio de Janeiro, tive a oportunidade de ouvir pela primeira vez o depoimento emocionado e emocionante da mãe de um dos jovens desaparecidos. Seu relato falava da violência policial, da violência dos traficantes, de tortura, da saudade do filho, do não acesso à justiça e de sua dor.

Passados exatamente dois anos e onze meses, lá estava eu reencontrando essa mesma mãe, Maria, para realizar uma entrevista. Nesse intervalo de tempo, encontrei-a em duas outras ocasiões: a primeira foi na entrega da Medalha Chico Mendes, numa cerimônia organizada pelo Grupo Tortura Nunca Mais ${ }^{3}$ a segunda foi no enterro de uma mãe que também havia perdido um filho e de quem Maria se tornara grande companheira, unidas pela mesma dor do desaparecimento dos filhos. Durante todo o processo de negociação da entrevista, Maria manifestou uma preocupação com as condições dos locais para a entrevista; deveria, antes de mais nada, ser em um lugar seguro.

A entrevista funcionou como uma via de transmissão e externalização de uma memória traumática. Tratava-se de uma memória da dor, memória dolo- 
rosa, agonística, porque sua publicização pode gerar incompreensões, desentendimentos e estigmatização. Em razão disso, é contada quase como um segredo, com um grande cuidado, para um pequeno círculo de interessados, apenas para aqueles que inspiram um mínimo de interesse e confiança. A entrevista foi uma forma de Maria narrar e compartilhar sua dor. ${ }^{4}$

Ao final de nosso encontro, quando nos dirigíamos ao ponto de ônibus, Maria me disse que chegou a pensar em não me conceder a entrevista, porque, segundo ela, desde que aconteceu a tragédia havia concedido muitas entrevistas para jornalistas e tinha sido muito mal compreendida. Ao ser publicada nos jornais, sua fala era alterada, editada, o que lhe desagradava.

Acredito que Maria levou adiante meu pedido de entrevista graças à identificação feita com pessoas que lhe eram próximas e também acompanhavam seu caso. Na verdade, o elo que ajudou a construir a confiança foram minhas relações anteriores com outros familiares e militantes de Direitos Humanos com os quais ela agora estava lidando em razão do desaparecimento de seu filho. Descrevo esses detalhes da negociação da entrevista para enfatizar o silenciamento e os obstáculos a serem enfrentados por essa mãe para se fazer ouvida.

Pode-se dizer que há um circuito restrito no qual as memórias da tragédia são compartilhadas e socializadas. A confiança é construída a partir dos laços de solidariedade que se estabelecem pelo compartilhamento da dor e pelo sofrimento da experiência traumática. São essas marcas que me foram gentilmente compartilhadas por Maria durante a entrevista. O teor dos acontecimentos narrados chega a provocar, conforme se poderá perceber na descrição da entrevista, certo mal-estar. E o pesquisador, nessas horas, torna-se "testemunha da testemunha" (Jelin, 2001), ou seja, desenvolve um trabalho de escuta da testemunha que fala em nome da vítima, já que esta última não se encontra presente para testemunhar. Há momentos em que as lágrimas escorrem pelo rosto de Maria, ao lembrar, com uma riqueza impressionante de detalhes, da tragédia. Isso aconteceu, por exemplo, quando ela me narrou uma situação em que, dentro de um ônibus que transitava pelas ruas do centro do Rio de Janeiro, enxergou uma pessoa do lado de fora que parecia ser seu filho. Desesperada, desceu do ônibus e saiu à procura desse rapaz, seguindo seus passos e rastros, até encontrá-lo e constatar que não era seu filho.

A lembrança provoca um sentimento de saudade, cujos efeitos traumáticos são tão fortes que chegam a transformar a saudade em angústia em razão da não localização do corpo do filho, nem vivo nem morto. Vive-se um luto que se estende pelo tempo, porque, como argumentou adequadamente a antropóloga Ludmila Catela, ao estudar os casos de desaparecimento forçado durante a ditadura argentina, o desaparecimento pode ser pensado como uma "morte inconclusa" (Catela, 2001, p. 142). Os rituais de morte e de despedida são rompidos, na medida em que não há corpo, em que não há um momento específico para o luto, e não há uma sepultura onde são depositados os restos mortais.

Como não há o corpo para comprovar a morte, Maria prefere acreditar que o filho esteja vivo. Ela me contou vários casos em que saía procurando o filho aleatoriamente pelas ruas da cidade. Por onde seu olhar passasse, era sempre mais uma tentativa de visualizar e encontrar o filho. Em certo momento da entrevista, conversávamos no alto de uma igreja, um lugar por meio do qual era possível avistar a movimentação da rua. Ao observar o movimento no ponto de ônibus, Maria identificou uma pessoa que parecia muito com seu filho. Nesse instante, seus olhos se encheram de lágrimas e ela começou a me descrever os gestos corporais de seu filho. Segundo ela, o andar da pessoa que estava passando lá fora era muito parecido com o andar de Alexandre. As formas de falar, de se vestir, de gesticular e de andar das pessoa, passaram a ser observadas por Maria, como se fossem pistas que ajudassem a identificar e localizar o filho.

\section{O "sumiço" do filho: tomando conhecimento da notícia}

A primeira notícia Maria recebeu da irmã pelo telefone: tinha ocorrido uma operação policial na favela e alguns jovens teriam sido levados dentro do "caveirão", entre eles seu filho. Outra versão que circulou era a de que os jovens menores de idade teriam sido levados para o Juizado de Menor. Maria conta que, no meio do desespero, perguntava-se por que seu filho teria sido levado ao Juizado de Menor e a resposta que ouviu da irmã foi que Alexandre estava saindo da favela, de madrugada, quando foi abordado. O simples fato de circular à noite pela favela é compreendido pela irmã de Maria como motivo suficiente de suspeição.

Maria seguiu do trabalho direto para a favela, apesar de não conhecer ninguém. Por ser obreira da igreja, ${ }^{5}$ as pessoas rapidamente a identificaram.

4. Para uma discussão sobre a produção social da identidade frente a situações- limite, conferir Pollak (2006).

5. Obreira da igreja: na linguagem evangélica, aquela pessoa que se engaja nas atividades e no trabalho da igreja. 
Quando ela chegou à "comunidade", 6 havia uma van estacionada e dentro dela mães e outros familiares dos jovens desaparecidos choravam. Quando os familiares de outros jovens se aproximaram de Maria, ela foi logo perguntando o que estava acontecendo. Informaram-lhe que todos ali estavam se dirigindo ao Batalhão responsável pela área para conversar com o comandante sobre a operação policial que ocorrera pela madrugada, na qual os jovens teriam desaparecidos. Entretanto, segundo rumores que circularam, os jovens não tinham sido levados para a Delegacia, mas sim entregues aos traficantes rivais da Favela Cutelo.

De acordo com os moradores ouvidos por Maria, os policiais entraram na Favela Samambaia, com o “caveirão", para dar cobertura aos traficantes da facção rival que desejavam tomar as bocas da favela. Um $\mathrm{X}-9^{7}$ teria se aproveitado da situação para se vingar do filho de Maria. Ela, no entanto, continuava sem entender por que levaram logo o seu filho e fazia essa pergunta às outras mães e aos familiares dos outros jovens sequestrados, até que obteve uma resposta mais precisa:

Quando o X-9 viu ele saindo de dentro comunidade, quando o "caveirão" passou, o menino virou pra um dos traficantes que estava dentro do "caveirão" e falou assim: "[Esse é] da favela, filho de um dos donos da favela. Aí pararam o 'caveirão' e colocaram ele”. Quando pegaram meu filho, diz que um dos chefes do tráfico falou o seguinte: "Ganhei na loteria, peguei o filho do cara". Aí, diz que ele ainda olhou para o meu filho e falou pro meu filho: "Nunca vi negro de nariz fino!". Porque meu filho tinha o nariz fino, mas fininho. "Nunca vi negro de nariz fino!". Diz que pegou o cortador do bolso, tirou um cortador de unha, eu não sei, e cortou um pedaço do nariz do garoto. Cortou um pedaço do nariz do meu filho. Quem conta essa história é um dos sobreviventes, um dos meninos que foi liberado, porque foram treze sequestrados.

Dos treze jovens sequestrados, cinco foram liberados, dois dos quais nunca foram identificados. Foram os três sobreviventes identificados que relataram a versão de que se tratava de treze jovens sequestrados por traficantes da favela rival, com a participação da polícia e de um X-9. Ao tomar conhecimento de que traficantes da Favela Cutelo estavam envolvidos no sequestro, Maria quis seguir para lá, mas os outros familiares seguraram-na na Favela Samambaia e depois, juntos, seguiram para a Delegacia de Polícia.

\section{Da Favela à Delegacia}

$\mathrm{Na}$ Delegacia encontraram o rapaz acusado de ser X-9. Ele estava preso e os familiares dos jovens desaparecidos não sabiam. Uma menina que estava no grupo de familiares dos jovens desaparecidos foi quem trouxe a informação: "Ele tá aí! Ele tá aí!”. Ao ouvir a fala dessa menina, Maria ficou curiosa em saber "quem estava ali". Guardava a esperança de ouvir que era seu filho, mas não era. Quem estava ali era o X-9. Maria ficou espantada ao saber quem era o X-9. Era um rapaz conhecido seu, para quem, segundo ela, "cansou" de fazer doações de alimentos já que a mãe desse rapaz era muito pobre e frequentava a mesma igreja que Maria. Desde muito cedo, ele também tinha o hábito de acompanhar sua mãe à igreja.

Maria relata que olhou "na parte de cima da Delegacia", lá estava X-9, com as mãos algemadas. Segundo ela, quando ele "bateu o olho nela", ficou "assim meio sem graça" e abaixou o olhar. No entanto, quando olhava para as outras mulheres, familiares dos outros jovens, ele as ameaçava. Maria começou a se sentir mal na Delegacia, mas ainda deu tempo de reconhecer dois jovens moradores de Samambaia que também estavam na Delegacia. Ao avistarem esses jovens, os familiares passaram a lhes perguntar por cada um dos desaparecidos, já que foram todos pegos juntos. Maria se dirigiu a um deles para solicitar notícias de seu filho:

Virei pra esse rapaz, que me olhava muito arregalado, e perguntei pra ele assim: "Meu filho, por favor", e peguei a foto do meu filho e mostrei pra ele. "Esse menino tava junto com vocês? Você viu se eles pegaram esse menino?". Ele ficou paralisado. Ele olhava pra mim, mas não conseguia me responder, sabe? Eu via o terror no olho dele, no rosto dele, e eu falei: "Meu filho, me responde! Esse menino tava com vocês?". E ele balançou um pouquinho a cabeça, quase não mexendo, assim pra mim, sabe? E aí ele abaixou a cabeça e a lágrima desceu no olho dele. Ai eu falei: "Meu filho, pelo amor de Deus, fala pra mim, o que foi que você viu? Esse menino tava no meio deles?". Esse menino não piscava nem nada. Ele olhava fixo dentro dos meus olhos e ficava paralisado assim. $\mathrm{O}$ olhar dele me deu medo, desespero. Porque eu olhei pra ele e tipo como se ele não quisesse falar! Aí eu virei as costas e bati com a mão na parede e falei: "O meu filho está morto! Eles mataram o meu filho e ele viu o meu filho morrendo". Aí, ele pegou e ficou assim... a lágrima dele descia. Ele abaixou a cabeça.

6. Comunidade é um termo utilizado por moradores de favela, e apropriado por outros atores (agentes estatais, ONG etc.), em substituição à palavra "favela", como forma de evitar o estigma e fugir das designações segregadoras de uso corrente na cidade do Rio de Janeiro. Para uma discussão dos diferentes usos políticos do termo "comunidade", conferir Birman (2008). 
Aí, eu não vi mais nada. Quando eu acordei, eu já estava lá dentro. Eu desmaiei e não conseguia falar. Eu fiquei oito horas sem ter voz. Fiquei paralisada, oito horas sem falar. Eu não conseguia falar uma palavra. Eu abria a boca e não saía. Eu fiquei paralisada, era como se eu tivesse tomado uma anestesia, alguma coisa, porque eu queria andar e minha perna não respondia. Aí eu fui tirada dali, me pegaram pelas pernas, me colocaram dentro de um carro e dali me levaram para um hospital, para o Getúlio Vargas.

Após desmaiar na Delegacia, Maria foi levada ao hospital. Segundo seu relato, quando voltou a si já era madrugada do dia seguinte. Do hospital foi levada para a casa de uma "moça da igreja", dentro da comunidade de Samambaia. Ao acordar de madrugada, ficou desesperada ao ver que não estava em casa e perguntou o que estava fazendo ali:

Aí a menina disse pra mim: "Você não pode voltar pra tua casa". Aí eu perguntei por que não. "Porque, segundo o comentário que tá tendo aqui dentro da comunidade, o teu filho foi pego por causa do seu ex-marido, e se você voltar pra casa eles vão lá pra te matar". Aí eu falei: "Gente, mas eu não tenho nada a ver com essa história. Eu trabalho, eu vivo a minha vida, e eu sou separada desse homem há doze anos. Quando eu vivia com ele, ele trabalhava, não era dessa vida". E a menina disse: "Não, você não pode voltar pra sua casa”. E aí eu fiquei lá dentro da comunidade, naquele desespero, de madrugada, andando pra lá e pra cá. Não queria dormir, eu queria meu filho. E eu andava dentro da comunidade, amanheceu o dia e nós fomos para o Batalhão

\section{Da Delegacia ao Batalhão: a conversa com o comandante}

A conversa com o comandante foi marcada pela tensão. As mães ficaram irritadas ao ouvir da boca do comandante que naquela madrugada ele não havia liberado nenhum carro blindado, ${ }^{8}$ sendo assim impossível que o "caveirão" tivesse circulado pela co- munidade. Maria contestou o comandante dizendo que na Favela Samambaia há uma ocupação policial que chega às dezoito horas e sai às seis da manhã, mas, nesse dia, a ocupação saiu da "comunidade" a uma e quarenta da manhã, para dar cobertura aos traficantes. Vários moradores teriam visto dois "caveirões" entrando na favela.

Diante do impasse, as mães pediram ao comandante que enviasse uma equipe à favela para procurar "os meninos". Junto com as mães estava o presidente da Associação de Moradores, que também ouviu da boca do comandante que não arriscaria seus policiais em Samambaia, porque, segundo ele, "o pessoal de Samambaia tem mania de dar tiro em polícia". As mães insistiram nesse pedido, mas não foram atendidas. Para encerrar a conversa, o comandante disse que nesse momento era horário escolar e seus soldados estavam ocupados, lanchando.

Segundo o relato de Maria, o comandante chegou a afirmar que, se o acontecimento tivesse ocorrido na Favela Cutelo, os policiais iriam, "porque lá é mais tranquilo". O comandante do Batalhão perguntou às mães se elas garantiriam a segurança dos policiais e se falariam com os "bandidos" para a polícia entrar. No meio do desespero, as mães disseram ao comandante que conversariam com quem quer que fosse, mas ao final da conversa saíram dali sem resposta alguma. Quando as mães estavam de saída, na porta do Batalhão, um dos familiares dos jovens recebeu um telefonema informando que os jovens estariam no Hospital Getúlio Vargas. Entraram na van e dali mesmo se dirigiram ao hospital.

\section{Do Batalhão ao Hospital: a presença ostensiva da polícia}

Ao chegarem ao hospital, não puderam entrar, pois uma grade de emergência havia sido colocada justamente na entrada para impedir a passagem. Maria segurou na grade e olhou para dentro do hospital. "Havia muita polícia", segundo ela, e um grupo de PM formava uma roda de conversa. Do lado de fora da grade, Maria tentava conversar com esses policiais,

\section{Blindado: o mesmo que caveirão, carro blindado.}

9. Caveirão: "O caveirão é um carro blindado adaptado para ser um veículo militar. A palavra caveirão refere-se ao emblema do Batalhão de Operações Policiais Especiais (BOPE), que aparece com destaque na lateral do veículo. Entre as modificações feitas nos caminhões blindados originais estão o acréscimo de uma torre de tiro, capaz de girar em 360 graus, e fileiras de posições de tiro em cada lado do caminhão. 0 caveirão tem capacidade para até 12 policiais com armas pesadas. Construído para resistir às armas de alta potência e aos explosivos, o caveirão tem duas camadas de blindagem, assim como uma grade de aço para proteger as janelas quando sustenta fogo pesado. Os pneus são revestidos com uma substância glutinosa que impede que sejam furados. As quatro portas travam automaticamente e não podem ser abertas pelo lado de fora - dois alçapões de escape, um na torre e outro no piso, podem ser usados em emergências. Embora pese cerca de 8 toneladas, o caveirão pode alcançar velocidades de até $120 \mathrm{~km} / \mathrm{h}$ " (Fonte: Relatório da Anistia Internacional: "Vim buscar sua alma": o caveirão e o policiamento no Rio de Janeiro, 19/7/2006). 
quando um deles seguiu em sua direção. Ela então lhe explicou o que havia acontecido e qual era o caso. Esse policial que a atendeu seria um dos quatro policiais que receberam os cinquenta mil reais pagos pelos traficantes pelo "aluguel" do "caveirão". Os familiares só souberam dessa informação mais tarde.

Sem saber que o policial que a atendeu era um dos envolvidos no caso, Maria pegou uma foto do filho, mostrou-lhe e perguntou se aquele rapaz estava ali, no hospital. Para pressionar, disse ainda ao policial que essa informação de que o filho estava no hospital lhe havia sido transmitida por um guardador de carro, morador da Favela Samambaia que havia machucado a perna e passado no hospital para se medicar. Esse guardador dissera à Maria que viu o filho dela com o nariz cortado e muito sangue escorrendo.

Após ouvir Maria, o policial pegou a foto, olhou-a, pediu para que esperasse um minuto e entrou no setor de emergência do hospital, onde estavam os demais policiais. Do lado de fora da grade, Maria via esse policial mostrar a foto de seu filho aos colegas de profissão. Do lado de dentro, o policial olhava para a foto e olhava para Maria. A fotografia passou de mão em mão. Um falava com o outro, e alguns riam balançando a cabeça.

Maria, que estava acompanhada da irmã, pediulhe que desse um jeito de recuperar a fotografia, que rodava de mão em mão entre os policiais. Enquanto a irmã tentava reaver a fotografia, Maria elaborou uma estratégia para conseguir entrar no hospital. Fez uma ficha médica, como se estivesse passando mal.

Dei a volta por baixo do setor de entrada de emergência, fiz uma ficha como se eu tivesse lá passando mal. Me afastei dali, desci e fui sozinha, fiz uma fichinha e entrei no hospital. Consegui entrar. Quando eu cheguei lá dentro, tinha dois rapazes numa maca. Um estava com a cabeça aberta, tipo que tinha ganhado uma machadada na cabeça, uma abertura horrível, com o rosto todo inchado, todo arrebentado. E eu tinha a outra foto comigo, né? Eu tenho um monte de fotos do meu filho dentro da bolsa. Aí eu perguntei para o rapaz assim: "Meu filho, você é do caso Samambaia?". E o rapaz todo arrebentado, assim: "Não, não, eu não sei de Samambaia não. Eu não sei de nada não!". Aí eu senti que era. Aí ele falou assim: "Eu não sou de Samambaia”. Aí eu virei as costas, quando eu virei as costas pra ele, quando eu dei uns cinco passos assim, ele virou e falou assim: “A senhora é a mãe do K?". Aí eu voltei e falei pra ele assim: "Eu não falei que você era de Samambaia? Você era do caso Samambaia?".

Depois de muito insistir com esse garoto e não obter nenhuma informação, Maria percorreu todo o hospital, e de novo não encontrou nada, nenhum indício. Tampouco ouviu alguma coisa relacionada ao caso Samambaia. Os familiares dos jovens desaparecidos se reuniram novamente, entraram na van e prosseguiram na peregrinação em busca de informações.

\section{Esperança e desespero}

Os dias iam passando e a angústia das mães só aumentava. Até que numa quinta-feira à tarde, $\mathrm{Ma}-$ ria foi a uma igreja evangélica e o pastor lhe disse que ligara para "dentro da comunidade" e falara com um rapaz que já havia sido pastor dessa mesma igreja e agora era traficante. Esse ex-pastor, convertido ao tráfico, falou com o chefe do tráfico (conhecido pelo apelido de Cafunga), e este lhe respondeu que liberava qualquer um dos meninos, menos esse, porque esse era o filho do "cara". Ou seja, não podia liberar, porque o pai do filho de Maria era um dos chefes do tráfico de uma facção rival. O poder sobre a vida e a morte do filho do traficante rival era uma forma de vingança. $\mathrm{Na}$ interpretação de Maria, os jovens sequestrados poderiam ser utilizados como escudo humano durante a invasão de uma favela pela facção rival ou também poderiam servir de moeda de troca para as negociações.

O sentimento de desespero se misturava ao sentimento de esperança, e ambos se embaralhavam. Afinal, se o pastor recebera a notícia de que poderia liberar qualquer um, menos o filho de Maria, isso significava que até aquele momento os jovens ainda estavam vivos. Poucos dias depois outra informação chocante chegou aos ouvidos de Maria e das outras mães:

Teve na sexta feira um baile funk em comemoração a isso, em Cutelo. E a informação que chegou em Samambaia era que os meninos estavam todos sentados, amarrados e nus, e conforme o espeto do churrasco ia esquentando, eles furavam os meninos, colocavam eles no telefone para os traficantes de Samambaia ouvirem e falavam: "Oh, a gente tá assando a carne dos filhos de vocês. Aqui, oh!”. E aí os meninos gritavam, choravam no telefone, e eles ficavam furando os meninos e fazendo aquelas torturas. No decorrer do tempo fui recebendo bastante informação, que eles iam trocar aqueles meninos de lugares, que eles iam usar aqueles meninos quando eles invadissem. Os meninos iam mostrar a cara dos traficantes. E aí houve o comentário que eles tinham sido mortos e picados e jogados para os porcos e os policiais mataram os porcos fizeram análise e não tinha vestígio de carne humana, não teria como em dois dias aqueles porcos comerem oito pessoas.

Apesar da versão de que os jovens teriam sido mortos, picados e jogados para os porcos, Maria não acredita nessa possibilidade. Ainda prefere acreditar 
que o filho está vivo. Passados mais de dois anos de quando ouvi o primeiro relato sobre o caso, na ocasião em que realizei a entrevista com Maria, seu entendimento era o de que a intenção dos traficantes de Cutelo, ao entrarem em Samambaia, era tomar o tráfico de drogas e não sequestrar os jovens. Para ela, os traficantes foram enganados pelo X-9:

Como K. tinha sido expulso da comunidade pelo traficante, por ter caguetado o pessoal do tráfico, passou para o pessoal de Cutelo e achou que ia concluir a vingança dele. Ele enganou os traficantes de Cutelo dizendo que sabia onde moravam [os traficantes de Samambaia]. Levou o chefe do tráfico somente na casa dos meninos que na época deram a surra nele. E eu fiquei sabendo que meu filho participou de bater nele. Então a vingança era do K. Ele usou o dono de Cutelo para concluir a vingança, mas o dono não sabia disso. E depois desses anos todos, eu descobri que os meninos saíram de dentro da comunidade de Samambaia nus, que eles tiraram as roupas deles e os levaram para Cutelo nus. Quem mora na divisa viu pela janela que os meninos passaram, todos eles amarrados. [O traficante] saiu de dentro da comunidade de Samambaia de “caveirão”. Por isso, nós nunca conseguimos encontrar os nossos filhos. Por isso que na manhã seguinte a Polícia Civil vasculhou tudo dentro da comunidade, e não achou esses meninos. Porque eles estavam no subterrâneo. ${ }^{10}$ Todas as denúncias que eu tive de lugares onde eles pudessem estar eu passei adiante. O coronel investigou e realmente encontrou vestígios. Parece que Cutelo fez um subterrâneo. É tipo um porão, onde ele [o coronel] encontrou uns cobertores. Do outro lado da favela, tinha um galpão abandonado. Encontraram vestígios de que realmente os garotos passaram por ali. E uma casa que ia ser uma igreja, teve denúncia de que eles foram torturados dentro dessa casa. Porque um dos meninos que foi libertado levou a polícia até esse local. E encontraram pedaços de dedos, encontraram muito sangue naquele lugar. Foi ali que foi feito aquele exame que se chama forense, ${ }^{11}$ né? Aquele exame que joga o luminol, ${ }^{12}$ que joga pra investigar sangue. Encontraram nove tipos de sangue diferentes.

Um dos garotos liberados participou da reconstituição dos fatos e apontou a casa de onde teria saído o homem chamado de "açougueiro", o responsável por picotar os corpos. No dia da reconstituição, o "açougueiro"13 foi preso e seria levado pela Polícia Civil ao Batalhão, mas os policiais teriam recebido mais dez mil reais para o liberarem. Maria faz questão de lembrar que todas essas informações foram divulgadas pela imprensa, foram publicizadas, e nenhuma medida foi tomada, porque se tratavam de policiais. A expectativa de Maria era que o "açougueiro" fosse dizer onde estavam os corpos dos jovens desaparecidos, mas, quando os policiais voltaram ao Posto de Policiamento, que fica na divisa de Samambaia com Cutelo, para conduzi-lo ao Batalhão, constataram que ele já havia sido liberado.

Ainda segundo Maria, nesse dia, quando chegou à Delegacia, o delegado encontrou os policiais contando dez mil reais da propina que receberam. Entretanto esse dinheiro não foi citado como prova contra os policiais. Nas palavras dela: "colocaram uma pedra em cima disso, porque tinha policiais envolvidos. Esses policiais ficaram em prisão administrativa durante trinta dias".

Maria contou também que o X-9 foi conduzido ao Batalhão para fazer o reconhecimento dos policiais que haviam liberado o "caveirão" para que fosse utilizado na invasão da favela. Foram colocados duzentos policiais para K. fazer o reconhecimento; dentre eles, o rapaz reconheceu quatro. Esses quatro policiais eram exatamente aqueles que estavam escalados para o policiamento em Samambaia. Na versão dos policiais acusados, eles teriam realmente sido chamados à Samambaia e houve uma operação policial.

Quando eles chegaram lá, tinha um menino que ia dizer pra eles onde os traficantes estavam e onde estavam as armas. K. ia conduzi-los às casas dos bandidos. Contaram no depoimento que foi isso que foram fazer lá. Só que em depoimento K. não diz isso. Diz o seguinte: que eles [os policiais] ficaram encarregados de trazer o "caveirão" e dentro do caveirão estavam ele, outro traficante magro, e o Cafunga. E quando eles chegaram na porta do "caveirão", o motorista do carro blindado falou o seguinte: "Uê! O que quê tá acontecendo? Oh, cara!? Você vai entrar aqui assim?”. Porque esse traficante estava armado, estava com granadas penduradas. E aí diz que os policiais do posto

\section{Subterrâneo: porão utilizado pelos traficantes como cativeiro, para esconder pessoas sequestradas}

11. Forense (exame forense): exame pericial para encontrar material que sirva como prova nos autos de um processo jurídico.

12. Luminol: é uma substância química criada em 1928 por H. O. Albrecht. É um produto que é preparado misturando-se o luminol propriamente dito com uma substância à base de peróxido de hidrogênio, que possui o mesmo efeito da água oxigenada e reage muito lentamente. Quando essa mistura entra em contato com o sangue humano, utiliza o ferro presente na hemoglobina como agente catalisador, causando uma reação de quimiluminescência. É muito utilizado pela polícia científica quando necessita saber se há vestígios de sangue em roupas, objetos ou lugares. No caso de tecidos, mesmo que a cena do crime tenha sido limpa, as fibras do tecido absorvem partes do composto de ferro e, assim, quando aplicado o luminol, ele causa uma reação de oxidação e "ilumina", literalmente, o local, ficando uma cor azul-fluorescente. É mais útil quando usado junto com luz-negra, podendo-se assim ver mais claramente as evidências de sangue.

13. Açougueiro: expressão utilizada para designar a pessoa, dentro do tráfico, responsável por torturar, matar e esquartejar corpos. 
de policiamento tranquilizaram os policiais que estavam indo ajudar eles. Disseram o seguinte: "Não, tá tranquilo, pode [deixar]. Eles são amigos, pode entrar que eles são amigos". Eles estavam todos fardados, os traficantes, com farda da PM. E aí eles entraram em Samambaia dessa maneira, com traficantes dentro do “caveirão”. E aí [os policiais] alegam que só tinha um carro blindado, mas os moradores de Samambaia ficam com medo de denunciar. [Os moradores] alegaram que eram dois carros blindados.

Maria conta que, através dos depoimentos dos policiais, os familiares descobriram que eles eram de vários batalhões diferentes. Essa informação também já havia sido passada pelo X-9, mas até então ninguém admitia. As mães só acreditaram quando tiveram acesso ao inquérito, em que constavam os depoimentos dos policiais, os nomes dos policiais denunciados e os respectivos batalhões aos quais eram vinculados.

Com o passar do tempo, novos detalhes e informações apareceram e novas surpresas também. Maria tomou conhecimento, a partir do relato das outras mães, que alguns dos "meninos" foram retirados de dentro de casa por traficantes vestidos com o uniforme da polícia.

Eles bateram de porta em porta. Alguns eles encontraram pelas vielas, pelos becos da comunidade. No caso do meu filho, na Ponte, já descendo. Então ele [o X-9] levou [os traficantes] na casa desses meninos, que antigamente eram amigos dele. Bateram na porta e falaram: "Vamos embora, vamos levar que é bandido". E diz que os policiais falaram o seguinte [para as mães]: "Se ele não for bandido, ele vai ser liberado, mas a gente vai levar para averiguação. Todos eles serão levados pra averiguação". E, aí, as mães naquele desespero, catando os documentos, indo atrás deles. Só que elas achavam muito estranho, porque elas olhavam para a cara de alguns que estavam vestidos de policiais e elas achavam que eram rostos conhecidos. Porque muitos moram na divisa de Samambaia e Cutelo. Mas como tinha polícia ali sempre, elas não achavam que eram bandidos. Só que quando o Cafunga entrou na casa de uma delas, ela reconheceu, porque ele era de Samambaia e as pessoas conheciam. Algumas mães foram atrás e eles gritaram pra elas voltarem, porque senão as matariam. E alguns meninos foram tirados de dentro de casa. E essas mães alegam que eles, os traficantes, estavam vestidos de PM. Só que pra gente comprovar... Se a gente fala essas coisas, a polícia sempre vem contra a gente. A polícia sempre diz: "Cuidado com o que você diz, a gente pode te processar". Eles estavam sempre falando esse tipo de coisa. E eu fui muito ameaçada. Porque as mães que moravam na comunidade, elas tinham muito medo, e eu já não tinha medo porque eu morava fora. Mas mesmo assim, era meu filho, eu tinha que correr atrás. Fui eu quem o botou no mundo. Ele dependia de mim, então eu tinha que fazer aquilo. E aí eu sei que elas [as outras mães] ficaram com muito medo. Eu fui ameaçada pelo comandante [do Batalhão] várias vezes. $\mathrm{Na}$ casa da minha mãe, teve muitas vezes que eu ia pra abrir o portão e eu dava de cara com ele num gol bolinha, perto da minha casa.

Em razão das ameaças que sofreu, Maria teve de mudar de casa consecutivamente, chegando a ter dezesseis endereços diferentes. Teve de abandonar tudo várias vezes, morar na casa de pessoas que não a conheciam, mas que foram solidárias e ofereceram-lhe abrigo. Diz que teve a promessa do governador de que teria outra casa, conversou com autoridades públicas que atuam na área dos direitos humanos, inclusive com o Ministro da Justiça Tarso Genro, mas não obteve resposta alguma. Uma carta chegou a ser enviada por uma autoridade à Caixa Econômica Federal, tratando de uma casa para Maria, porém também não resultou em nada.

A única coisa que as mães receberam, por curto período de tempo, foram algumas cestas básicas. A partir desse fato, Maria elabora uma crítica às outras mães. No seu entendimento, as cestas básicas eram dadas para poder calar a boca das mães, porque, diz ela, "nós sabemos que as pessoas que vivem na comunidade, o que oferecem pra elas, elas aceitam". Já a interpretação que Maria faz de si mesma é a de que levantou uma bandeira, porque foi contra a polícia, foi contra traficante, foi contra todo mundo, porque achava um absurdo ninguém fazer nada.

Para Maria, as outras mães tiveram medo de se manifestarem porque moravam dentro da favela, e qualquer manifestação significaria risco de morte. Por isso, preferiram calar-se (ou melhor, foram silenciadas). Conta ainda que convidava as outras mães para reuniões, manifestações, viagens, para denunciar o caso e reivindicar providências, mas ninguém aparecia. Uma das peregrinações solitárias de Maria se deu quando ela decidiu solicitar uma dragagem de um rio que fica em Samambaia, após receber uma denúncia de que os corpos poderiam ter sido jogados em um valão. $O$ valão ficava próximo a um terreno da Marinha, só sendo permitida a entrada com a autorização desta. Este foi o maior obstáculo. Maria chegou a conseguir a draga para fazer a busca no rio e, depois de muito empenho e mobilização, conseguiu, por intermédio de uma assessora do então senador e ex-ministro da justiça Renan Calheiros (PMDB/AL), autorização para entrar na área.

Fui a única que botou peito pra dragar o rio. Andei na comunidade toda espalhando papel, colhendo assinatura, mobilizando pra poder pedir para dragar o rio. E não dragaram. Disseram que dragaram ali não 
sei quantos metros, cinquenta metros, cem metros. Mas, se eles tivessem dragado pelo menos cinquenta metros, eu tenho certeza de que eles teriam encontrado pelo menos cem corpos. Qual foi o medo de dragar aquele rio? Porque se eles dragam aquele rio [seria] pior do que o tsunami, [apareceriam] milhares de corpos. Ia ser um escândalo, e a [governadora] Rosinha não queria isso no final do mandato dela. Entendeu? Então tem sido uma luta muito grande. Eu cheguei pra uma das mães e falei pra ela: "Por que você não vai comigo?". "Maria, é melhor você botar uma pedra em cima disso, eu não quero saber dessa coisa. É melhor deixar essa coisa pra lá”.

A crítica de Maria ao envolvimento das mães se situa na fronteira entre a compreensão e a resignação. $\mathrm{O}$ choque e o trauma do acontecimento foram muito fortes e provocaram um impacto tão grande sobre as outras mães que Maria acaba relativizando a própria crítica:

Eu só via [sofrimento] naquelas mães. A Ângela até hoje sofre. A Ângela e a Joana sofrem. A Joana foi embora pra Pernambuco, ela é de lá. Ela foi embora e não quer mais voltar pra cá, entrou em estado de depressão, de choque, que não saía nem pra ir ao supermercado fazer compra. Então eu não estou questionando o sentimento das mães, porque cada um tem o seu sentimento e cada um reage de uma maneira. E eu sei que elas têm medo. E tinham medo porque foram ameaçadas naquela época, por causa de tudo. Porque nós estivemos no Batalhão e elas tinham medo. E eu não, como eu já morava fora, eu tinha como me locomover. Eu ia pra qualquer lugar, não vivia presa dentro daquilo ali, dentro de favela, dentro de comunidade. Então eu sei que elas tiveram muito medo e elas largaram tudo. E até foi ter o julgamento e só a Maria estava no julgamento. Em todas as audiências só estava eu. Viagem pra Brasília, falar com o ministro da Justiça, era eu. Direitos humanos, era eu. Vai pra uma manifestação, era eu.

Diante da negativa das outras mães em participar e levar o caso adiante, Maria sentiu que não adiantava mais contar com elas. Em sua fala expressa uma grande indignação com o fato de as mães se recusarem a procurar os filhos. Recorrendo à religião, Maria justifica sua força para prosseguir na luta, diz que sentiu Deus falando dentro de seu coração: "Maria, cada um daqueles meninos é teu filho, teu filho não é só o Alexandre. Acabou. Você não é mais mãe só do Alexandre. Não conta com elas, porque você não pode contar com elas".

\section{O jogo de denúncias e a manipulação das provas}

Uma das principais dificuldades na luta das mães por justiça e reparação é a produção de provas que incriminem os acusados. Mesmo quando existem provas fartas e evidentes, o corporativismo policial aparece como obstáculo ao prosseguimento dos processos e/ou as testemunhas e familiares são intimidados e forçados a alterarem seus depoimentos ou até a se mudarem de cidade.

Diante da negação do comandante de que teria ocorrido uma operação policial naquela madrugada e de que nenhum "caveirão" havia entrado na favela, Maria enumera o que considera provas suficientes para que sejam tomadas providências urgentes e sérias: dedos; sangue; restos de roupa; ossadas; grande quantidade de dinheiro encontrada com policiais; testemunhos de moradores que assistiram, de dentro de casa, os acontecimentos; relatos das mães que tiveram suas casas invadidas e o exame de DNA. Tudo isso, no entendimento de Maria, são provas suficientes para demonstrar que a tragédia aconteceu e que providências precisam ser tomadas.

Alguns rapazes, acusados de serem "traficantes", chegaram a ser presos e foram em juízo fazer o reconhecimento dos policiais. No entanto, acabaram colocados em liberdade e não mais apareceram no julgamento dos policiais. A libertação dos "traficantes" presos apavorou as mães, pois eles andavam dizendo que as matariam. Maria conta que estava dentro da Defensoria Pública quando recebeu o telefonema da delegada dizendo que o advogado de Cafunga havia conseguido uma liberdade condicional. Ela então perguntou ao defensor público o que seria das mães com a libertação de Cafunga:

Eu falei pra ele: "Doutor, estão falando que o Cafunga vai sair hoje [da prisão], como vão ficar as mães? Ele vai querer matar as mães". Ele falou o seguinte: "É, dona Maria, eu te aconselho o seguinte: a senhora comprar uma pistola, esperar ele sair de dentro da Delegacia e matar ele. Pode deixar que eu te defendo, você não vai presa não".

Percebe-se que cada visita a um órgão público se tornava mais decepcionante e traumática que a outra. Segundo Maria, as investigações do caso pelos delegados e pelas Delegacias por onde passou não progrediram em nada. Os delegados responsáveis pela investigação não lhe inspiravam nenhuma confiança. Um deles, numa ocasião, tentou esconder os exames de DNA que as mães dos jovens desaparecidos fizeram. Quando o delegado tentou negar a existência dos exames de DNA das três mães, Maria argumentou que 
era impossível que eles não existissem, já que foram esses exames que serviram como prova contra um dos traficantes, aquele que havia prometido matar as mães.

O delegado titular que acompanhava o caso chegou a dizer à Maria que ela poderia ficar tranquila, pois o exame tinha dado positivo, e isso serviria para manter Cafunga preso. Entretanto, não mostrou o exame a ela. Em umas das idas à Delegacia, foi informada que o delegado titular havia entrado de férias. Quem a atendeu, na ocasião, foi o delegado substituto. Depois de uma longa espera, segundo Maria, veio a decepção. Apesar de ela nunca ter visto o resultado do seu exame e o das duas outras mães, as autoridades policiais the disseram que os resultados haviam sido negativos. No entanto, para ela, isso não importava. O resultado de outros quatro exames já dera positivo, e era o que bastava. No seu entendimento, havia evidências suficientes para que a investigação progredisse. Além de quatro resultados de DNA positivos, Maria pergunta: "Cadê o dedo que encontraram na casa?". Ela mesma se encarrega de responder que ninguém nunca viu.

Até pedaço de carne humana e ossadas foram encontradas. A respeito das ossadas, os policiais disseram que seriam de cavalo, mas mesmo assim foram levadas para a Delegacia junto com alguns restos de roupas para a perícia. As mães foram até lá fazer o reconhecimento do material encontrado e Maria foi a última a chegar. Ela relata que era vista pelos policiais como a mãe "cricri", que "gostava de criar problemas". Quando chegou à Delegacia, um policial tocava no outro com o objetivo de informar que era ela a mãe "cricri". $\mathrm{Na}$ Delegacia, os policiais estavam mostrando dois sacos pretos às mães: um de roupas parcialmente queimadas e o outro com a ossada. Para Maria, mostraram apenas o saco de roupas. Não a deixaram ver o saco com a ossada, mas as mães que viram lhe informaram que era uma ossada humana com uma perfuração na cabeça. No exame realizado pela polícia, o resultado informava que a ossada seria de um animal.

\section{O pai, a favela e o baile funk: a presença do perigo e do mal}

Na narrativa de Maria é possível identificar um conjunto de pessoas, eventos, lugares e interações sociais que ela elege como perigosos, arriscados e moralmente condenáveis. Essas pessoas, eventos, lugares e interações sociais simbolicamente são associados ao mal, por isso seria preciso evitá-las. Gerir o risco significa evitar todo um repertório de relações e práticas sociais identificadas ao mal, ao impuro e ao perigo. Ao mal está associada ideia de poluição, de algo que contagia e contamina (Douglas, 1976). Por isso é preciso afastar-se, manter distância. De acordo com Maria, o pai de seu filho, a favela e o baile funk são figuras, lugares e situações sociais associadas ao perigo e ao risco, razão pela qual devem ser evitados.

Maria não se conforma com a associação que é feita dela e do filho ao ex-marido. O envolvimento do pai de Alexandre com o crime acabou por produzir uma "contaminação moral" aos familiares e às pessoas mais próximas. Nas versões que circularam sobre o caso, um dos motivos mencionados para justificar o desaparecimento era o fato de Alexandre ser próximo de uma pessoa que já havia sido "do tráfico". Ela não consegue entender como isso poderia justificar o desaparecimento do filho, por dois motivos: ao mesmo tempo em que descreve uma relação de proximidade entre Alexandre e o pai envolvido com a criminalidade, Maria tenta demarcar uma distância dela e do filho em relação ao pai. Diz que esse rapaz que ela conheceu não era o pai biológico de Alexandre. Quando ela o conheceu, ele não era do crime e hoje também já não é mais.

A preocupação e o amor materno levam Maria a passar por situações e lugares compreendidos por ela como "poluídos moralmente", como a favela e o baile funk. Tudo em nome da segurança do filho. Há toda uma noção de cuidado em sua fala. Cuidar significa, nesse caso, tentar prever todas as possíveis situações de risco e perigo e evitá-las. O baile funk é um desses lugares; está associado, nas representações sociais hegemônicas, às facções, ao uso e tráfico de drogas, à promiscuidade sexual, ao perigo de a polícia chegar ou ao de uma facção rival "invadir". Por tudo isso, Maria chegava a subir o morro para buscar o filho nos bailes.

Como o filho tinha o costume de frequentar a favela, o trabalho de limpeza moral (Leite, 2008) tornava-se mais difícil. Frequentar o baile era um fato negativo que pesava contra a imagem do filho. Mas, para mostrar que o filho não era bandido, Maria conta toda a rotina diária e a ocupação do tempo de Alexandre como prova moral de que ele não tinha tempo para se envolver em atividades criminosas e, portanto, não era bandido.

Outra situação que deixa Maria desesperada era o fato de Alexandre compor letras de funk. Dentre as representações sociais hegemônicas sobre o funk há aquelas que o associam a uma forma de expressão e linguagem do tráfico. Os "proibidões" ${ }^{14}$ seriam uma

14. Proibidões (de proibidão): é um estilo de funk carioca surgido durante a década de 1990 nas favelas do Rio de Janeiro. Comercializado de forma clandestina, os proibidões tratam da realidade das comunidades onde há tráfico de drogas. É considerado por muitos como uma forma de apologia ao tráfico de drogas e também com uma forte dimensão sexual nas letras. 
forma de mandar recado e ridicularizar a facção rival, e, ao mesmo tempo, celebrar o poder e a força da facção à qual se está associado. Nas letras de funk de Alexandre, ele cantava que iria arrancar a cabeça de Cafunga.

\section{A memória das tragédias, 0 trabalho de luto e a reivindicação de justiça}

Pode-se dizer que há um circuito restrito no qual as memórias da tragédia são compartilhadas e socializadas. A confiança é construída através dos laços de solidariedade que se estabelecem a partir do compartilhamento da dor e do sofrimento da experiência traumática. A lembrança da tragédia torna-se um recurso identitário. Segundo Candau (2001, p. 147-148),

a memória das tragédias pertence ao registro dos acontecimentos que, [...], contribuem para definir o campo do memorável. É uma interpretação, uma leitura da história das tragédias. É também uma memória forte. Memória das dores e memória dolorosa, memória da desgraça que é sempre "a ocasião de levantar as verdadeiras perguntas", a memória das tragédias deixa marcas compartilhadas durante muito tempo por aqueles que as padeceram ou cujos seres queridos a padeceram, modificando profundamente suas personalidades.

A partir do desaparecimento forçado e da ausência dos corpos se estabelece uma relação entre luto e justiça. Viver o luto passa a significar reivindicar a justiça. Trata-se de um tipo de luto, cuja perda originou-se de um ato compreendido como injusto. Nesse contexto, o amor materno é mobilizado para justificar a reivindicação de justiça. Em um meu trabalho anterior (Araújo, 2008), sugiro que os "familiares de vítimas de violência" têm elaborado um formato de protesto que pode ser pensado como práticas de luto reivindicativas de justiça, enquanto em outros casos nota-se uma vivência silenciosa. No caso particular apresentado neste artigo, o relato da mãe corresponde a uma verdadeira narrativa do terror e do sofrimento. O evento crítico inscreve-se nas memórias, no corpo e na subjetividade dessa mãe.

\section{Referências}

ARAÚJO, Fábio. Falta alguém na minha casa: desaparecimento, luto, maternidade e política. In: KANT DE LIMA, Roberto (Org.). Antropologia e direitos humanos 5. Brasília: Booklink/ ABA/Fundação Ford, 2008. BIRMAN, Patricia. Favela é comunidade? In: MACHADO DA SILVA, Luiz Antonio (Org.). Vida sob cerco: violência e rotina nas favelas do Rio de Janeiro. Rio de Janeiro: Nova Fronteira, 2008.

BOLTANSKI, Luc. El amor y la justicia como competências: três ensayos de teoria de la acción. Buenos Aires: Amorrotu, 2000.

CANDAU, Jöel. Memoria e identidad. Buenos Aires: Del Sol, 2001.
DAS, Veena. Critical events: an antropology perspective on contemporany India. New Delhi: Oxford University Press, 1995.

DOUGLAS, Mary. Pureza e perigo: ensaio sobre as noções de poluição e tabu. São Paulo: Perspectiva, 1976.

JELIN, Elizabeth. Los trabajos de la memória. Madrid: Siglo XXI, 2001.

LEITE, Márcia Pereira. Violência, risco e sociabilidade nas margens da cidade: percepções e formas de ação de moradores de favelas cariocas. In: MACHADO DA SILVA, Luiz Antonio (Org.). Vida sob cerco: violência e rotina nas favelas do Rio de Janeiro. Rio de Janeiro: Nova Fronteira, 2008, 


\title{
Narrative of terror and suffering: motherly accounts on her son's disappearance
}

\begin{abstract}
The forced disappearance of persons was used as a method of repression during the military regimes in Latin America today is a practice of the repertoire of the language of urban violence. In this article I present and analyze the reports of a mother about the passing of his son, played by "drug trafficker" in partnership with police. The story is emblematic of this mother, being a true narrative of terror and suffering and my main interest is to trace the history of pain exploring the potency of the account collected.
\end{abstract}

Key words: forced disappearance; mourning; family of victim; favela; maternity.

\section{Narrativa de terror y de sufrimiento: relatos maternos acerca de la desaparición forzada del hijo}

\section{Resumen}

La desaparición forzada de personas fue utilizada como un método de represión durante los regímenes militares en América Latina, hoy día es una práctica del repertorio de la lengua de la violencia urbana. En este artículo se presenta y se analiza los informes de una madre sobre la muerte de su hijo, protagonizada por "narcotraficantes", en colaboración con la policía. La historia de esta madre es emblemática, al ser un relato verdadero de terror y sufrimiento y mi objetivo principal es trazar la historia angustiosa de explorar la potencia de la cuenta de recogida.

Palabras clave: desaparición forzada; duelo; familiar de víctima; favela; maternidad.

Data de recebimento do artigo: 10/05/2011

Data de aprovação do artigo: 29/07/2011 